\title{
Spor Bilimleri Fakültesi Öğrencilerinin İletişim Becerisi Düzeyleri ile Genel Öz Yeterlilik Algıları Arasındaki İlişkinin İncelenmesi
}

DOI: 10.26466/opus.639999

\author{
Kenan Koç* - Mehmet Behzat Turan** - Tuba Akgül Arslan *** \\ * Dr. Öğr. Üyesi, Erciyes Üniversitesi Spor Bilimleri Fakültesi/ Kayseri/ Türkiye \\ E-Posta: kenankoc@erciyes.edu.tr \\ ORCID: $\underline{0000-0002-1459-2655}$ \\ ** Araş.Gör.Dr., Erciyes Üniversitesi Spor Bilimleri Fakültesi/ Kayseri/ Türkiye \\ E-Posta: behzatturan@erciyes.edu.tr \\ ORCID: 0000-0002-5332-803X
}

*** Yüksek Lisans Öğrencisi, Erciyes Üniversitesi Sağlık Bilimleri Enstitüsü/ Kayseri/ Türkiye

E-Posta: tubaakgul@hotmail.com

ORCID: $\underline{0000-0002-3226-3927}$

\section{Öz}

Bu araştırmanın amacı, üniversite öğrencilerinin İletişim becerileri ile genel öz yeterlilik alguları arasındaki ilişkinin incelenmesidir.Bu amaç doğrultusunda örneklemi; Erciyes Üniversitesi Spor Bilimleri Fakültesi, 2018-2019 eğitim öğretim yılında Beden Eğitimi ve Spor Öğretmenlĭ̆i, Antrenörlük, Rekreasyon ve Spor Yöneticiliği bölümlerinden rastgele yöntemle seçilmiş 314 gönüllü öğrenciden oluşmaktadır. Araştırmada veri toplama araçları olarak; İletişim Becerilerini Değerlendirme Ölçeği ve Genel Öz yeterlilik ölçeği ile araştırmacı tarafindan hazırlanmış demografik bilgi formu kullanılmıştır.Demografik Bilgi Formundan ve ölçeklerden elde edilen veriler SPSS 20.0 paket programı ile istatistiksel analizleri yapılmıştır. Adaylara ilişkin kişisel bilgiler ve envanter toplam puanları ve faktör puanları frekans $(f)$ ve yüzde $(\%)$ değgerleri tespit edilerek verilmiştir. Ölçeklerden elde edilen puanlarm arasındaki ilişkiyi ortaya koyabilmek için Pearson Momentler Çarpımı Korelasyon analizi ( $r$ ) ve elde edilen puanlarının birbirinin yordayıcı olup olmadı̆̆ını tespit edebilmek için Çoklu regresyon analizi uygulanmıştır ( $\beta$ ). Iletişsim becerisi ile genel öz yeterlilik toplamı ve alt boyutları arasında anlamlı ve doğrusal bir ilişki olduğu tespit edilmiştir.Çalışmanın sonuçlara bakıldığında iletişim becerisi birçok alanı etkilediği gibi öğrencilerin genel öz yeterlilik algısın da etkilemiştir. Bu nedenle eğitim programları hazırlanırken bireysel farklılkların göz önünde bulundurularak iletişime açık sosyal ortamlarm çoğaltılması ve kişilik özelliklerine dikkat edilmesinin önemli olduğu düşünülmektedir.

Anahtar Kelimeler: : İletişim Becerisi, Genel Öz yeterlilik, Beden Eğitimi Öğretmenliği 


\title{
Investigation of the Relationship Between Communication Skills Levels and General Self- Efficacy Perceptions of Faculty of Sport Sciences Students
}

*

\begin{abstract}
The aim of this study is to investigate the relationship between communication skills and general selfefficacy perceptions of university students. This intended sample; Erciyes University Faculty of Sport Sciences, 2018-2019 Physical Education and Sports Teaching, Coaching, Recreation and Sports Management departments consist of 314 randomly selected volunteers.

As data collection tools; Demographic information form including the Communication Skills Development Scale and General Self-Efficacy Scale. Obtained data from demographic information form and scales were analyzed statistically with the SPSS 20.0 package program. The personal information and inventory total scores and factor scores for the candidates were determined by determining frequency (f) and percentage (\%) values. Multiple regression analysis $(\beta)$ was used to determine whether Pearson Moments Multiplication Correlation analysis ( $r$ ) and their scores were predictive of each other in order to reveal the relationship between scores obtained from the scales.There is a significant and linear relationship between communication skills and total self-efficacy total and sub-dimensions. When the results of the study were examined, communication skills might also affect the field area and also affected the general self-efficacy perception. Make sure that the training programs in this student are explained before the check. I think that reproduction of open social environments is a priority without paying attention to personal characteristics.
\end{abstract}

Keywords: Communication Skills, General Self-efficacy, Physical Education Teacher 


\section{Giriş}

İnsan ilişkilerinin yoğun olduğu ortamlarda çalıştığı söylenebilecek Beden Eğitimi öğretmenleri, Antrenörler ve Spor yöneticilerinin insan ilişkilerini kolaylaştırıcı becerilere sahip olmaları gerektiği düşünülmektedir. Spor bilimleri multidisipliner bir alandır. Spor bilimleri alanında eğitim öğretim almaya hak kazanan aday eğitmenler, fiziksel yetilerinin yanı sıra eğitim öğretim süreci içerisinde; eğitim bilimleri, tıp bilimleri, psiko-sosyal alanlar, antrenman bilimi gibi alanlarda öğrenim olanağına sahiptirler (Sevimli vd., 2010)

İnsanların olayları görerek, duyarak ve yaşayarak uygulamasına imkân sağlayan ve bireysel farklılıkları göz ardı etmeyen spor ortamlarında, iletişimi etkili kılacak becerilerin öğrenilmesi ve sosyal yaşama aktarılması sağlanabilir. Bu nedenle beden eğitimi öğretmenleri, antrenörler ve spor yöneticilerinin bu konuda donanımlı yetiştirilmeleri ilişkide bulundukları bireylere iletişim becerilerini kazandırmak amacıyla önemli görülmektedir. Ayrıca her bireyin zorunlu eğitim sürecinden geçtiğini ve eğitim programlarında beden eğitimi dersinin zorunlu olduğunu düşünürsek beden eğitimi öğretmenlerinin bu becerilere sahip olmasının daha da önemli olduğu söylenebilir (Tepeköylü vd., 2009). Etkili iletişim becerisi, her bireyin özel hayatında ve öğrenim sürecinde olduğu gibi meslek hayatında da kendini ifade edebilmek, anlatabilmek, karşısındakini anlayabilmek, çatışmaları önleyebilmek ya da yönetebilmek, çıkan problemleri çözebilmek için, kısacası kendisiyle ve sosyal çevresiyle anlaşabilmesi için ihtiyaç duyduğu temel beceridir (Lahninger, 1999). Bu bakımdan eğitimde önemli yer tutmaktadır (Nünning ve Zierold, 2008). İnsan, sosyal yapısı gereği diğer bireylerle iletişim kurma ihtiyacı içindedir. Bireyler arasındaki iletişim, bireylerdeki ilişki kurma ihtiyacından ve karşılıklı olarak birtakım hedeflere ulaşma çabasından doğar (Johnson, 1990). Karşıllıklı iletişim, karşılıklı etkileşime yol açar. İnsanlar gönderdikleri mesajlarla başkalarını etkiledikleri gibi, başkalarından gelen mesajlarla da kendileri etkilenmektedirler (Baymur, 1990).

Günümüzde insanlar ile doğru ve düzgün iletişimde bulunamamak en sık olarak karşımıza çıkan ve artık kronikleşmeye başlamış olan sıkıntıların en temelinde bulunmaktadır. İnsanlar ile doğru iletişim kuramamanın nedeni ise hem kendi iç sesimize yeterince önemsemiyor oluşumuz hem de diğer kimselerin duygularını anlamakta zorluk çekmekten kaynaklanmak- 
tadır. İletişim becerisini tek başına ele almak olanaksızdır pek çok değişken iletişimi etkilemektedir. Özellikle kişinin kendini algısı bu noktada belirleyici bir rol üstlenmektedir. Kendini nasıl algıladığı ve içsel saygısı aynı zamanda diğer kişilerle iletişimi ciddi şekilde etkilemektedir bu bağlamda öz yeterlilik duygusu, iletişim açısından önemli bir belirleyici olarak düşünülebilir. Bireyin belli bir edimi gerçekleştirmek için gerekli eylemleri düzenleme ve yürütme gücüne ilişkin yargısına öz (benlik) yeterlik denilmektedir (Bandura, 1997). Öz yeterlik algısının, bilişsel süreçlerde anahtar bir güdüleyici rolü vardır (Çetin, 2008). Bandura, (1997) öz yeterlik algısının, insan davranışlarının ve davranış değişikliklerinin temel belirleyicilerinden biri olduğunu, bireyin becerileri konusundaki inançlarının, sadece davranışların1 değil, düşünme süreçlerini ve güdüsünü de etkilediğini belirtmektedir. Öz yeterlik inancı yüksek olan insanlar yeni karşılaştıkları ve mücadele etmek durumunda oldukları yaşantılardan kaçmazlar ve eylemlerini başarı11 bir şekilde tamamlamak için oldukça kararlı davranmaktadırlar.

Birey ne kadar potansiyele ve avantaja sahip olursa olsun belli bir konuda yeterlilik hissetmiyorsa eyleme başlama ve sürdürme konusunda güçlük yaşayabilir. Bu durum bir kısır döngü haline gelebilir. Bu kısır döngü bireyin genel olarak yetersizlik duygusunu hissedip, kendisini potansiyellerine rağmen ifade edememesine hatta engellemesine, bir diğer ifadeyle kendisini gerçekleştirememesine neden olabilir. Olumlu öz yeterlik algısına sahip bireylerin isteyerek eyleme girişmelerinin yanı sıra, güçlükler karşısında daha dayanıklı ve ısrarcı oldukları; zorlu işleri, kaçınılması gereken eylemler olarak değil, üzerinde çalışıp kendilerini geliştirmeleri gereken alanlar olarak algıladıkları görülmektedir (Pajares ve Schunk, 2001).

Öz yeterlik algıları üniversite öğrencileri içinde önemli bir etkendir. Çünkü üniversite dönemi bireylerin kendilerini gerçekleştirmede önemli bir yaşam dönemidir. Ergenlikten yetişkinliğe geçiş aşaması olan bu dönemde öğrenciler birçok farklı durumla karşılaşabilmektedir. Kimlik krizi, kuşak çatışması, sosyal beklentiler ile kişisel isteklerde uyuşmazlık, karşı cinsle olan ilişkiler, yaşanan biyolojik değişim ve yerine getirilmesi gereken gelişimsel görevler gibi pek çok etken ergenlik sürecinde bireylerin yaşamını etkilemektedir (Onur, 2001; Ünal ve Şahin, 2013).

Bu bilgiler 1şığında yapılan bu çalışmanın amacı; Spor Bilimleri Fakültesi öğrencilerinin, iletişim becerileri ile genel öz yeterlilikleri arasındaki ilişkinin incelenmesidir. 


\section{Yöntem}

\section{Araştırma Modeli}

Araştırmada, mevcut durumu ortaya çıkartmayı amaçlayan betimsel ve ilişkisel taramaya yönelik bir yöntem kullanılmıştır. Betimsel taramada araştırmaya konu olan olay, birey ya da nesne kendi koşulları içinde ve olduğu gibi tanımlanmaya çalışılır. İlişkisel tarama modelleri ise iki ve daha çok sayıdaki değişken arasında birlikte değişim varlığını ve/veya derecesini belirlemeyi amaçlayan araştırma modelleridir (Karasar, 2004).

\section{Çalışma Grubu}

Çalışma grubu Erciyes Üniversitesi Spor Bilimleri Fakültesi, 2018-2019 eğitim öğretim yılında Beden Eğitimi ve Spor Öğretmenliği, Antrenörlük, Rekreasyon ve Spor Yöneticiliği bölümlerinden 1. 2. 3. ve 4. sınıflarında öğrenim gören 1378 öğrenciden basit tesadüfi yöntemle ile seçilmiş (Çıng1, 1994) 314 gönüllü öğrenciden oluşmaktadır. Araştırma grubunu oluşturan öğrencilere ait kişisel bilgiler Tablo 1'de gösterilmiştir.

Tablo 1. Katılımcılarn Sosyo-demografik Özellikleri

\begin{tabular}{|c|c|c|c|}
\hline & Değişken & $\mathbf{N}$ & $\%$ \\
\hline \multirow{2}{*}{ Cinsiyet } & Kadın & 154 & 49.0 \\
\hline & Erkek & 160 & 51.0 \\
\hline \multirow{4}{*}{ Yaş } & $18-21$ & 193 & 61.5 \\
\hline & $22-24$ & 94 & 29.9 \\
\hline & $25-27$ & 15 & 4.8 \\
\hline & $28+$ & 12 & 3.8 \\
\hline \multirow{5}{*}{ Kardeş Sayısı } & 0 & 9 & 2,9 \\
\hline & 1 & 15 & 4.8 \\
\hline & 2 & 86 & 27.4 \\
\hline & 3 & 109 & 34.7 \\
\hline & $4+$ & 95 & 30.3 \\
\hline \multirow{3}{*}{$\begin{array}{l}\text { Anne Baba } \\
\text { Birliktelik Durumu }\end{array}$} & Evet & 277 & 88.2 \\
\hline & Hayır & 36 & 11.5 \\
\hline & Boşandılar & 1 & .3 \\
\hline \multirow{7}{*}{ Anne Eğitim Durumu } & Okur-yazar değil & 17 & 5.4 \\
\hline & Okur-yazar & 29 & 9.2 \\
\hline & İlokul mezunu & 122 & 38.9 \\
\hline & Ortaokul mezunu & 75 & 23.9 \\
\hline & Lise mezunu & 53 & 16.9 \\
\hline & Üniversite mezunu & 12 & 3.8 \\
\hline & Lisansüstü & 6 & 1.9 \\
\hline
\end{tabular}




\begin{tabular}{llll}
\hline & Okur-yazar değil & 7 & 2.2 \\
& Okur-yazar & 14 & 4.5 \\
& İköğretim mezunu & 95 & 30.3 \\
& Ortaöğretim mezunu & 80 & 25.5 \\
& Lise mezunu & 73 & 23.2 \\
& Üniversite mezunu & 33 & 10.5 \\
& Lisansüstü & 12 & 3.8 \\
\hline \multirow{3}{*}{ Ailenin Ekonomitim Durumu } & Düşük & 27 & 8.6 \\
& Orta & 131 & 41.7 \\
& İyi & 115 & 36.6 \\
& Çok iyi & 41 & 13.1 \\
\hline \multirow{2}{*}{ Eğitim Kurumundan Memnuniyet Düzeyi } & Evet & 207 & 65.9 \\
& Hayır & 107 & 34.1 \\
\hline
\end{tabular}

Tablo 1'e bakıldığı zaman erkeklerin ortalaması \% 51 iken kadınların ortalaması \% 49 olarak görülmektedir. Yaş değişkeni incelendiğinde katılımc1ların \% 61.5'i 18-21 aralığında, \% 29.9'u 22-24 aralığında, \%4.8'i 25-27 aralığında ve \%3,8'ine bakıldığında 27+ yaştadır. Anne Baba birliktelik durumları incelendiğinde, katımcıların \%88.2 si Birlikteler, \%11.5'i Birlikte değiller ve \%0.3'ü Boşandılar yanıtını vermektedir. Anne Eğitim Durumuna bakıldığında, \%5.4'ü Okur yazar değil, \%9.2'si okur yazar, \%38.9'u İlkokul mezunu, \%23.9'u Ortaokul mezunu, \%16.9 Lise mezunu, 3.8'i Üniversite mezunu ve \%1.9'u Yüksek Lisans/Doktora ve üzeri yanıtını vermiştir. Baba Eğitim Durumuna bakıldığında, \%2.2'si Okur yazar değil, \%4.5'i Okur yazar, \%30.3'ü İlköğretim mezunu, \%25.5'i Ortaöğrtim mezunu, \%23.2'si Lise mezunu, \%10.5'i Üniversite mezunu ve \%3.8'i Yüksek Lisans/Doktora ve üzeri yanıtını vermiştir. Katılımcıların Aile Ekonomik Durumuna bakıldığında \%8.6'sı Düşük, \%41.7'si Orta, \%36.6'sı İyi ve \%13.1'i Çok iyi olarak yanıt vermiştir. Katılımcların Eğitim Kurumundan Memnuniyet Düzeyi incelendiğinde, \%65.9'u Evet \%34.1'i Hayır yanıtını vermiştir.

\section{Veri Toplama Araçları}

Araştırmada öğrencilere uygulanan olan anketlerin uygulanması esnasında araştırmacının yanı sıra üniversitede görev yapan öğretim elemanları tarafından adayların her birine geniş bir zaman dilimi içerisinde, acele edilmeden, gerekli açıklamalar yapılarak, adaylar için sağlıklı bir değerlendirme süreci yaratılmaya çalışılmıştır. Ayrıca adayların rahat bir ortamda formları doldurmaları amacı ile uygun materyal ve çevre koşulları sağlanmıştır. 
Araştırmada kullanılan veri toplama araçları; İletişim Becerilerini Değerlendirme Ölçeği ve Genel Öz yeterlilik ölçeği ile araştırmacı tarafından hazırlanmış demografik bilgi formudur.

İletişim Becerilerini Değerlendirme Ölçeği:Araştırmada Korkut (1996) tarafından geliştirilen 25 maddeden oluşan iletişim becerilerini değerlendirme ölçeği kullanılmıştır. Katılımcılardan ölçekteki her bir maddenin karşısında yer alan hiçbir zaman, nadiren, bazen, genellikle, her zaman $(0,1,2,3,4)$ ifadelerinden birini seçmeleri beklenmektedir. İlk çalışmalarda 0-4 ile puanlanan ölçek son yapılan çalışmalarda 1.5 şeklinde puanlanmıştır . Bu çalışmada ise 0-4 ile puanlama yapılmıştır. Ters kodlu maddelerin olmadığı bu ölçekten alınabilecek en yüksek puan 100, en düşük puan ise 0'dır. Ölçekten alınan puanın yüksekliği bireyin kendisini iletişim becerileri açısından olumlu olarak değerlendirdiğini göstermektedir. Ölçeğin iç tutarlık güvenirliği için Cronbach alfa katsayısı hesaplanmış ve 25 maddelik ölçeğin iç tutarlık katsayısı .88 olarak hesaplanmıştır. Ölçeğin alt faktörlerine ilişkin iç tutarlık katsayıları ise, İ̈TB için .79; KİE için .72; EDSOİ için .64 ve İKİ için ise, .71 olarak belirlenmiştir.

Genel Öz yeterlilik Ölçeği:Schwarzer ve Jerusalem'in (2005) geliştirdikleri ve 25 'ten fazla dile uyarlaması yapılan Genel Öz Yeterlik Ölçeği (GÖYÖ)'nin Türkçe uyarlaması üç farklı üniversiteden toplam 693 öğrenci üzerinde yapılan çalışmayla Aypay (2010) tarafından yapılmıştır. Ölçeğin orijinal adı "General Self-Efficacy Scale" dır. Uyarlama çalışmasında ölçek formu 2005- 2006 öğretim yılı güz döneminde 711 öğrenciye uygulanmış ve katılımlarında gönüllülük esasına uyulmuştur. Ölçeğin geçerlik ve güvenirlik çalışmaları geçerli kabul edilen 693 ölçekteki veriler kullanılarak yapılmıştır. AFA sonucunda, toplam varyansın \% 47'sini açıklayan ve öz değeri 1 'den büyük olan iki faktör elde edilmiştir. Döndürme öncesinde tüm ölçek maddelerinin ilk temel bileşenden pozitif yönde ve $.47^{\prime}$ nin üzerinde yük aldığ görülmüştür. İlk temel bileşenin öz değeri 3.66'dır. Maddelerle ilgili olarak tanımlanan iki faktörün ortak varyanslarının bir madde dişında .33 ile .63 arasında değiştiği görülmüştür. GÖYÖ'nün ölçüt geçerliğini incelemek için, Türküm'ün (2002) Stresle Başa Çıkma Ölçeği (SBÖ) ve Rosenberg'in Öz Saygı Ölçeği (RÖSÖ) kullanılmıştır. GÖYÖ ile SBÖ'nün bütünü arasında anlamlı bir ilişki bulunmazken, GÖYÖ ile SBÖ'nün Soruna Yö- 
nelme Alt Ölçeğinden alınan puanlar arasında (r=.40, p<.001) pozitif yönde, orta düzeyde anlamlı bir ilişki vardır. GÖYÖ ile RÖSÖ puanları arasında $(\mathrm{r}=.38, \mathrm{p}<.001)$ yine pozitif yönde, orta düzeyde anlamlı bir ilişki vardır.

\section{Verilerin Analizi}

Kişisel Bilgi Formu, İletişim Becerileri Değerlendirme Ölçeği ve Genel Öz Yeterlilik Ölçeğinden elde edilen veriler kodlanarak bir istatistik programına girilmiş ve analizler bu program aracılığı ile yapılmıştır. Ölçeklere ait çarpıklık ve basıklık değerlerinin -1 ve +1 aralığında olduğu tespit edilmiştir Bu değerlerin -1 ve +1 aralığında yer almasının normallikten aşırı sapmalar olmaması şeklinde yorumlanmaktadır (Büyüköztürk, 2007). Bu bilgiler 1şığında verilerin normal dağılım gösterdiği kabul edilmiştir. Ölçeklerden elde edilen puanların arasındaki ilişkiyi ortaya koyabilmek için Pearson Momentler Çarpımı Korelasyon analizi ve elde edilen puanlarının birbirinin yordayıcısı olup olmadığını tespit edebilmek için çoklu regrasyon analizi uygulanmıştır.

\section{Bulgular}

Tablo 2. Katılımcıların ölçeklerden aldığı puanların betimsel istatistiği

\begin{tabular}{lllll}
\hline & N & Minimum & Maksimum & X \pm SD \\
\hline İletişim Toplam & 314 & 11,00 & 100,00 & $72.46 \pm 16.26$ \\
\hline Çaba ve Direnç & 314 & 6,00 & 24,00 & $19.34 \pm 3.28$ \\
\hline Yetenek ve Güven & 314 & 4,00 & 16,00 & $13.31 \pm 2.98$ \\
\hline Genel Özyeterlilik Toplamı & 314 & 10,00 & 40,00 & $32.65 \pm 5.68$ \\
\hline
\end{tabular}

Tablo 2 incelendiğinde iletişim toplam ortalamasının 72.46 olduğu hesaplanırken, , çaba ve direnç ortalamasının 19.34, yetenek ve güven ortalamasının 13.31, genel öz yeterlilik toplamı ortalaması 32.65 olarak hesaplanmiştır.

Tablo 3 incelendiğinde, iletişim toplamı ile çaba ve direnç arasında $(\mathrm{r}=$ ,527, $\mathrm{p}<0.00$ ) pozitif yönde yüksek ilişki bulunmuştur. İletişim toplamı ile yetenek ve güven arasında $(r=, 455, \mathrm{p}<0.00)$ pozitif yönde yüksek ilişki ve iletişim toplamı ile genel öz yeterlilik toplamı arasında $(\mathrm{r}=, 544, \mathrm{p}<0.00)$ pozitif yönde yüksek ilişki tespit edilmiştir 
Tablo 3. Gönüllülerin, iletişim becerilerinin genel öz yeterlilikleri arasındaki korelasyon katsayılarn

\begin{tabular}{|c|c|c|c|c|c|}
\hline Ölçekler & & 1 & 2 & 3 & 4 \\
\hline \multirow{3}{*}{ İletişim Toplam ${ }^{1}$} & $r$ & 1 & & & \\
\hline & $\mathrm{p}$ & & & & \\
\hline & $\mathrm{N}$ & 314 & & & \\
\hline \multirow{3}{*}{ Çaba ve Direnç² } & $\mathrm{r}$ &, $527^{* *}$ & 1 & & \\
\hline & $\mathrm{p}$ & 000 & & & \\
\hline & $\mathrm{N}$ & 314 & 314 & & \\
\hline \multirow{3}{*}{ Yetenek ve Güven ${ }^{3}$} & $\mathrm{r}$ & $455^{* *}$ & ,640* & 1 & \\
\hline & $\mathrm{p}$ & 000 & ,000 & & \\
\hline & $\mathrm{N}$ & 314 & 314 & 314 & \\
\hline \multirow{3}{*}{ Genel Öz yeterlilik Toplam ${ }^{4}$} & $\mathrm{r}$ & ,544" & ,915 & $896^{* *}$ & \multirow{3}{*}{$\begin{array}{l}1 \\
314\end{array}$} \\
\hline & $\mathrm{p}$ & ,000 & ,000 & ,000 & \\
\hline & $\mathrm{N}$ & 314 & 314 & 314 & \\
\hline
\end{tabular}

${ }^{* *} p<0.001$

Tablo 4. Öğrencilerin İletişim Beceri Düzeylerinin, Genel Özyeterlilik Düzeylerini Yordamasına Yönelik Regresyon Tablosu

\begin{tabular}{|c|c|c|c|c|c|c|c|c|}
\hline & & $\beta$ & $\mathbf{t}$ & $p$ & $R$ & $R^{2}$ & $\mathbf{F}$ & p \\
\hline \multirow{2}{*}{$\begin{array}{l}\text { İletişim } \\
\text { Becerisi }\end{array}$} & Genel Öz &, 544 & 11,442 & ,000 & \multirow[b]{2}{*}{,544 } & \multirow[b]{2}{*}{ 296 } & \multirow[b]{2}{*}{130.927} & \multirow[b]{2}{*}{,000 } \\
\hline & $\begin{array}{l}\text { yeterlilik } \\
\text { Toplam }\end{array}$ & & & & & & & \\
\hline
\end{tabular}

$F(1.312)$

Tablo 4 incelendiğinde iletişim Becerisi ve Genel Özyeterlilik arasında oluşturulan model anlamlı ilişki sunmaktadır.( $R=, 544 \mathrm{R} 2=, 296$; $p<.005)$ regresyon katsayısının anlamlılığına ilişkin t-testi sonuçları incelendiğinde; 'genel öz yeterliliki ( $t=11,442 \mathrm{p}=.005)$, İletişim becerisinin genel öz yeterliliği yordadığı ve toplam varyansın \% 29.6 sını açıkladığı görülmüştür.

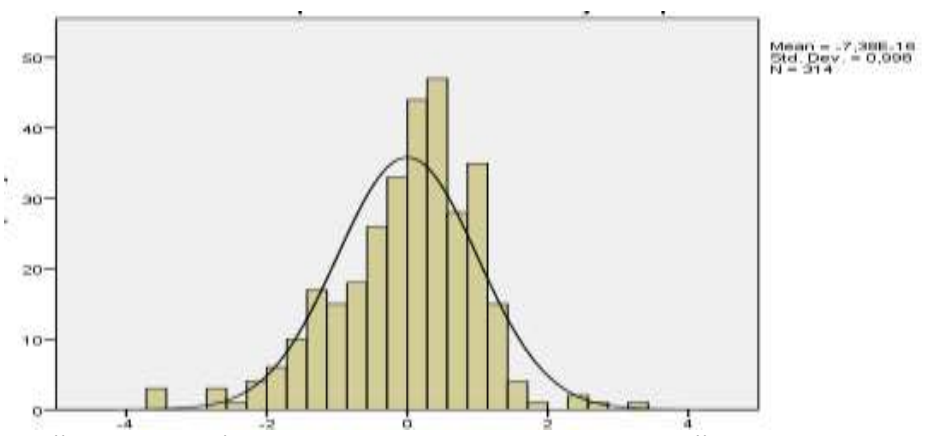

Grafik 1. Öğrencilerin İletişim Beceri Düzeylerinin, Genel Özyeterlilik Düzeylerini Yordamasına Yönelik Histogram 


\section{Tartışma ve Sonuç}

Araştımanın bulguları incelendiğinde iletişim becerisi ile genel öz yeterlilik arasında pozitif yönlü anlamlı ilişkler tespit edilmiştir.Ayrıca genel öz yeterlilik alt boyutları olan; çaba ve direnç, yetenek ve güven ile iletişim becerisi arasında anlamlı ilişkiler tespit edilmiştir. İletişim becerisi ve genel özyeterlilik arasındaki ilişkinin varyansı $\% 29,6$ olarak hesaplanmıştır.

Literatür incelendiğinde; Çiftçi ve Taşkaya'nın (2010) sınıf öğretmeni adaylarının öz yeterlik algıları ve iletişim becerileri arasındaki ilişkiyi ortaya çıkarmak amacıyla yaptığı çalışmada, eğitim fakültelerinin 4. sınıfında öğrenim gören sınıf öğretmeni adaylarının öz yeterlik ve iletişim becerilerinin ne düzeyde olduğu incelenmiş. Çalışma sonuçlarına göre, sınıf öğretmenliği bölümünde okuyan öğretmen adaylarını iletişim becerileri ile öz yeterlik algiları arasında pozitif yönde anlamlı bir ilişki olduğu tespit edilmiştir.

Nacar ve Tümkaya'nın (2011) sınıf öğretmenleriyle yaptığı çalışmada öğretmenlerin iletişim becerileri ve kişiler arası problem çözme becerileri arasında anlamlı bir ilişki olduğu tespit edilmiştir.Baydar Posluoğlu (2014) ilkokul öğretmenlerinin İletişim yeterlilikleri ile empati kurma becerileri arasındaki anlamlı ilişki olduğunu tepit etmiştir. Kesicioğlu ve Güven (2014) tarafından yapılan çalışmada;okul öncesi öğretmen adaylarının problem çözme becerileri, iletişim becerileri ve empati becerilerinin, öğretmen adaylarının öz yeterlik algılarını anlamlı bir şekilde yordadığı tespit edilmiştir.Özer (2017), "Öğretmenlerde Sosyal Kaygı Düzeyi ile İletişim Becerilerinin Bazı Değişkenler Açısından İncelenmesi” adlı çalışmasında, öğretmenlerin sosyal kaygı düzeyleri ile iletişim becerileri arasındaki ilişkiyi belirlemeyi amaçlamıştır. Araştırmada 188 öğretmene iletişim becerileri ölçeği ve sosyal kaygı ölçeği uygulamıştır. Araştırma sonuçlarına göre, öğretmenlerin iletişim becerileri arttıkça sosyal kaçınma, değerlendirilme kaygısı, değersizlik duygusu ve sosyal kaygının azaldığı sonucuna ulaşılmıştır.Küpelinin (2019) 401 ortaokul öğretmenleri üzerine yaptı̆̆ı araştırmaya göre;iletişim becerilerinin öz yeterlik algılarını orta düzeyde anlamlı olarak yordadığ belirlenmiştir. Buğdayc (2018) 697 antrenöre yaptığı tez çalışmasının sonucunda iletişim beceri ile öz yeterlilikleri arasında pozitif yönlü doğru orantılı bir ilişki olduğunu rapor etmiştir.

Sosyal Öğrenme Kuramı'na göre; bireylerin duygu, düşünce, güdü ve eylemlerini denetlemelerini sağlayan bir "ben sistemleri" bulunmaktadır ve 
bu sistem bireye davranışlarını algılama, düzenleme ve değerlendirme sürecinde kullanabileceği bir tür "ön düzenleyici düzenek ya da mekanizma" olarak destek sağlamaktadır. Bu mekanizma; bireylere gerçekleştirdikleri eylemin sonuçları, başarı düzeyi ve çevreye etkileri doğrultusunda bir belirleme yapma olanağı sunmakta ve bu belirlemeler de, daha sonraki davranışlar üzerinde belirleyici olmaktadır (Buğdaycı, 2018). Dolayısıyla kişinin bu sosyal ortam kendine olan güveni ve kendini algı şeklinin iletişimdeki kabileyitinide etkileyeceği düşünülmektedir.

Yapılan tanımlamalar ve literatürdeki diğer çalışmalar da incelendiğinde iletişim becerisi ve genel özyeterlilik arasında doğrusal yönlü bir ilişki olmasının anlamlı olduğu görülmektedir. Sonuç olarak spor bilimleri fakültesi öğrencilerinin iletişim becerileri arttıkça genel öz yeterliliklerininde artacağ ve bu becerileri geliştirici etkinliklerin eğitim ortamlarını zenginleştireceği düşünülmektedir.

\section{Öneriler}

- Uluslararası alanda akademisyenlerle iş birliği yapılıp öğretmen adaylarına değişim programları düzenlenerek farklı sosyal, kültürel ve iletişimin yoğun olduğu ortamlar sağlanabilir.Bu şekilde farklı ülkelerin öğretmen adayları ile iletişim kuran üniversiteli gençliğimizin öz güveni ve yeterliliği arttırlabilir.

- İletişim becerisi ve öz yeterlilik alanları branşlara göre farklılık arz edebilir bu yüzden her branşa yönelik iletişim ihtiyaçları ve mesleki yeterlilik alanları belirlenerek uygulamalı eğitimler yapılabilir

- Uzamsal metod kullanılarak öğretmen adaylarının uzun soluklu meslek hayatları boyuca gerekli olan kişisel gelişim ihtiyaçları ve bahsi geçen becerilerdeki seviyeleri ölçülüp gerekirse hizmet içi eğitimlerle güncellemeler yapilabilir.

- Ileride nesillere yön verecek öğretmen adayları branşlarının teknik bilgilerinin yanı sıra öğrencilerinin psikolojik yönlerini geliştirecek donatılarıda üniversite eğitimleri boyunca staja giderek pilot uygulamalarla alabilirler. 
EXTENDED ABSTRACT

\section{Investigation of the Relationship Between Communication Skills Levels and General Self-Efficacy Perceptions of Faculty of Sport Sciences Students \\ *}

Kenan Koç - Mehmet Behzat Turan -Tuba Akgül Arslan

Erciyes University

It is thought that Physical Education teachers, Coaches and Sports managers, who can be said to work in environments with intensive human relations, should have skills to facilitate human relations. Sports science is a multidisciplinary field. Candidate trainers who are entitled to receive education in the field of sports sciences, as well as their physical abilities; They have the opportunity to study in fields such as educational sciences, medical sciences, psycho-social fields, and training science (Cult et al., 2010).

Being unable to communicate properly and properly with people today is at the heart of the most common problems that we encounter and are now beginning to become chronic. The reason for not communicating properly with people is that we do not care enough about our inner voice and also have difficulty understanding the feelings of other people. It is impossible to address communication skills alone. Many variables affect communication. Especially self-perception plays a decisive role at this point. How he perceives himself and his inner respect also seriously affects communication with other people. In this context, sense of self-efficacy can be considered as an important determinant in terms of communication.

People with high self-efficacy beliefs do not escape from their new encounters and struggles and are very determined to complete their actions successfully.No matter how much potential and advantage the individual has, he / she may have difficulty in starting and maintaining action if he / she does not feel competence in a certain subject. This situation can become a vicious circle. This vicious circle can cause the individual to feel the sense of inadequacy and not to express themselves even in spite of their potential, in other words, to not realize themselves. Individuals with a positive self- 
efficacy perception are more resilient and persistent in the face of difficulties, as well as intentionally taking action; It is seen that they perceive difficult jobs not as actions to be avoided but as areas where they should work and develop themselves (Pajares and Schunk, 2001).

Self-efficacy perceptions are an important factor among university students. Because the university period is an important life period for individuals to realize themselves. In this period of transition from adolescence to adulthood, students may encounter many different situations. Many factors affect the life of individuals during adolescence, such as identity crisis, generational conflict, social expectations and incompatibility in personal requests, relationships with the opposite sex, biological change and developmental tasks to be fulfilled (Onur, 2001; Ünal and Şahin, 2013).The purpose of this study conducted in the light of this information; It is the study of the relationship between the communication skills and general self-efficacy of the Faculty of Sport Sciences students.

The study group was selected by simple random method from 1378 students studying in the Physical Education and Sports Teaching, Coaching, Recreation and Sports Management departments in the 2018-2019 academic year at Erciyes University Faculty of Sports Sciences (Çıngı, 1994). It consists of 314 volunteer students. Data collection tools used in the research; It is a demographic information form prepared by the researcher with the Communication Skills Evaluation Scale and the General Self-efficacy scale.

It is assumed that the obtained data show normal distribution. In order to reveal the relationship between the scores obtained from the scales, the Pearson Moments Product Correlation analysis and multiple regression analysis were used to determine whether the scores obtained were predictive of each other.

When the findings of the research were examined, significant positive relationships were found between communication skills and general selfefficacy. significant relationships were identified between effort and resistance, ability and confidence, and communication skills. The variance of the relationship between communication skill and general self-efficacy was calculated as $29.6 \%$.

According to Social Learning Theory; There is a "I systems" that enables individuals to control their emotions, thoughts, motives and actions, and this system provides support to the individual as a kind of "pre-regulatory 
mechanism or mechanism" that they can use in the process of perceiving, organizing and evaluating their behavior. This mechanism; it offers individuals the opportunity to make a determination in accordance with the results of their actions, their level of success and their effects on the environment, and these determinations are also determinative on the subsequent behaviors (Buğdayc1, 2018). Therefore, it is believed that this social environment will affect the self-confidence and self-perception of the tribe in communication.

When the definitions and other studies in the literature are also examined, it is seen that there is a significant relationship between communication skills and general self-efficacy. As a result, it is thought that as the communication skills of the students of the faculty of sports science increase, their general self-efficacy will increase, and activities that develop these skills will enrich the educational environment.

\section{Kaynakça / References}

Aypay, A. (2010). Genel öz yeterlik ölçeği'nin Türkçeye uyarlama çalışması. İnönü Üniversitesi Eğitim Fakültesi Dergisi, 11(2), 113-131.

Bandura, A. (1986). Social foundations of thought and action: A social cognitive theory. Englewood Cliffs, NJ: Prentice-Hall.

Bandura, A. (1997). Self-efficacy: The exercise of control. New York: W.H. Freeman and Company.

Baymur, F. (1990). Çağımızda insan ilişkilerinin artan önemi ve bu hususun eğitimde dikkate alınması, Psikolojik Danışma ve Rehberlik Dergisi,1, 16-17.

Buğdaycı, S. (2018). Antrenörlerin iletişim becerileri ile öz yeterliliklerinin incelenmesi. Yayınlanmamış Doktora Tezi, Selçuk Üniversitesi, Sağlık Bilimleri Enstitüsü. Konya

Büyüköztürk, Ş. (2007). Sosyal bilimler için veri analizi el kitabı. (7.Bask1), Pegem Akademi Yayınclık, 40.

Çetin, B. (2008). Marmara üniversitesi sınıf öğretmeni adaylarının bilgisayarla ilgili öz yeterlilik algılarını incelenmesi. D.Ü.Ziya Gökalp Eğitim Fakültesi Dergisi, 11, 101-114.

Çıngı, H. (1994). Örnekleme kuramı. Ankara: Hacettepe Üniversitesi Basımevi.

Çiftçi, S., ve Taşkaya, S.M. (2010). Sınıf öğretmeni adaylarını öz yeterlilik ve iletişim becerileri arasındaki ilişki. 9. Ulusal Sinıf Öğretmenliği Ĕ̆itimi Sempozyumu: Bildiriler kitabı içinde (s.509-512). 
Johnson, D.M. (1990). Reaching out: interpersonal effectiveness and self-actualization , Prentice Hall International Inc.

Karasar N. (2004). Bilimsel araştırma yöntemi. (17.baskı), Ankara:Nobel Yayın Dağ1tim, 49-53.

Korkut, F. (1996). İletişim becerilerini değerlendirme ölçeğinin geliştirilmesi: güvenirlik ve geçerlik çalışmaları. Psikolojik Danışma ve Rehberlik Dergisi, 2(7), 18-23.

Küpeli, E. (2019) Ortaokul öğretmenlerinin iletişim becerileri ile öz yeterlik algıları arasindaki ilişkinin incelenmesi. Yayınlanmamış Yüksek Lisans Tezi, Kahramanmaraş Sütçü İmam Üniversitesi Sosyal Bilimler Enstitüsü Eğitim Bilimleri Ana Bilim Dalı, Kahramanmaraş.

Lahninger, P. (1999). Lebendig und kreativ leiten präsentieren moderieren. arbeits- und methodenbuch für teamentwicklung und qualifizierte Aus- \& Weiterbildung. Münster Ökotopia Verlag

Nacar, F.S. ve Tümkaya, S. (2011). Sınıf öğretmenlerinin iletişim ve kişilerarası problem çözme becerilerinin incelenmesi. Elemantary Education Online, 10(2), 493-511.

Nünning, A. ve Zierold, M. (2008). Kommunikation skompetenzen. Erfolgreich kommunizieren in Studium und Berufsleben. Stuttgart: Klett.

Onur, B. (2001). Gelişim psikolojisi, yetişkinlik, yaşlılık, ölüm. (5. Baskı). Ankara: İmge Kitapevi.

Özer, A.R. (2017). Öğretmenlerde sosyal kaygı düzeyi ve iletişim becerilerinin bazı değişkenler açısından incelenmesi. Yüksek Lisans Tezi, Nişantaşı Üniversitesi Sosyal Bilimler Enstitüsü, İstanbul.

Pajares, F., ve Schunk, D. H. (2001). Self-beliefs and school success: Self-efficacy, selfconcept, and school achievement. In R. Riding ve S. Rayner (Eds.), Selfperception (p. 239-266). London: Ablex Publishing.

Sevimli, D. Çam, S. Dinç, Z. Dikici, K. ve Durusoy, A. (2010). Beden eğitimi ve spor yüksek okulu özel yetenek sınavını kazanan öğrencilerin öss puanlarının genel başarılarına etkisinin incelenmesi, Journal of New World Sciences Academy, 32. ISSN: 1308-7312.

Tepeköylü, Ö. Soytürk, M. ve Çamliyer, H. (2009). Beden eğitimi ve spor yüksekokulu (besyo) öğrencilerinin iletişim becerisi algılarının bazı değişkenler açısından incelenmesi", Spormetre Beden Eğitimi ve Spor Bilimleri Dergisi, 7(3) $115-124$ 
Ünal, A.Ö. ve Şahin, M. (2013). Lise öğrencilerinin yaşam doyumlarının bazı değişkenlere göre yordanması. Cumhuriyet International Journal of Education, 2(3), 46-63.

Kaynakça Bilgisi / Citation Information

Koç, K., Turan, M, B. ve Akgül Arslan, T. (2020). Spor bilimleri fakültesi öğrencilerinin iletişim becerisi düzeyleri ile genel öz yeterlilik algıları arasındaki ilişkinin incelenmesi. OPUS-Uluslararası Toplum Araştırmaları Dergisi , 15(26), 4421-4436. DOI: 10.26466/opus.639999 